University of Nebraska - Lincoln

DigitalCommons@University of Nebraska - Lincoln

Faculty Publications - Modern Languages and Modern Languages and Literatures, Department Literatures

2018

\title{
Sins, Sex, and Secrets: The Legacy of Confession from the Decameron to the Heptaméron
}

Nora Martin Peterson

University of Nebraska-Lincoln, npeterson10@unl.edu

Follow this and additional works at: https://digitalcommons.unl.edu/modlangfacpub

Part of the Comparative Literature Commons, European Languages and Societies Commons, and the Modern Languages Commons

Peterson, Nora Martin, "Sins, Sex, and Secrets: The Legacy of Confession from the Decameron to the Heptaméron" (2018). Faculty Publications - Modern Languages and Literatures. 32.

https://digitalcommons.unl.edu/modlangfacpub/32

This Article is brought to you for free and open access by the Modern Languages and Literatures, Department of at DigitalCommons@University of Nebraska - Lincoln. It has been accepted for inclusion in Faculty Publications Modern Languages and Literatures by an authorized administrator of DigitalCommons@University of Nebraska Lincoln. 


\section{Sins, Sex, and Secrets: The Legacy of Confession from the Decameron to the Heptaméron}

NORA MARTIN PETERSON

All the faithful of either sex, after they have reached the age of discernment, should individually confess all their sins in a faithful manner to their own priest at least once a year, and let them take care to do what they can to perform the penance imposed on them. Let them reverently receive the sacrament of the eucharist at least at Easter unless they think, for a good reason and on the advice of their own priest, that they should abstain from receiving it for a time ... Let this salutary decree be frequently published in churches, so that nobody may find the pretence of an excuse in the blindness of ignorance. If any persons wish, for good reasons, to confess their sins to another priest let them first ask and obtain the permission of their own priest; for otherwise the other priest will not have the power to absolve or to bind them. The priest shall be discerning and prudent, so that like a skilled doctor he may pour wine and oil over the wounds of the injured one. Let him carefully inquire about the circumstances of both the sinner and the sin, so that he may prudently discern what sort of advice he ought to give and what remedy to apply, using various means to heal the sick person. Let him take the utmost care, however, not to betray the sinner at all by word or sign or in any other way. If the priest needs wise advice, let him seek it cautiously without any mention of the person concerned.

- Lateran IV, Canon 21 (“On yearly confession to one's own priest”) ${ }^{1}$

The Fourth Lateran Council of 1215 brought about a new age in the history of penance. Now institutionally mandated of all members of the Christian community, the sacrament of confession took front and centre stage as the mechanism through which all sinners had to pass on the road to salvation in the Eucharist. It also served as a regulatory 
device by which confessors sought to control various sins and tensions between neighbours and, eventually, as a tool with which to tap the secret desires of the individual. ${ }^{2}$ This trajectory was not, however, a linear one. Scholars have disagreed about whether or not penance was already an influential practice in pre-Lateran congregations. Some have argued that the full extent of Lateran IV was not widely felt until as late as the fifteenth and sixteenth centuries, shortly before and then during the time of religious reform. ${ }^{3}$

Despite uncertainty, based largely in lack of documentation, about the prevalence of confession and the details surrounding the stringency with which, by whom, and where it was enforced, the deep influence of sacramental confession on fictional literature need not be disputed. The circulation of confessional discourse is widely reflected in nonliturgical texts spanning the period between Lateran IV (1215) and the Council of Trent (1545-63). The Decameron (1353) and the Heptaméron (1559) are both excellent texts to read together with the development of the sacrament of confession, as each one reflects the changing status of confession as well as its very real presence in their respective cultures. A quick digital search in the Decameron Web archive for the term "confess" in Boccaccio's Decameron yields seventy-five results. ${ }^{4}$ Confession in Boccaccio's text is conspicuously present and, I argue, not coincidental; I believe that roughly one hundred years after the formal induction of the practice of confession, the trope of confession had become a stronghold of the Christian community. In what follows, I will follow the hypotheses put forth by those such as John Bossy and Alexander Murray, who write about confession in the first few centuries before and after Lateran IV as largely public, or, if private, focused on absolution immediately before death. ${ }^{5}$ The confessions in the Decameron follow the formulaic structure of confession manuals, which were appearing in great numbers during Boccaccio's time. The outcome of successful confession is directed towards the group rather than the individual. ${ }^{6}$

Confession, as both a narrative device and a religious sacrament, is built into both texts. But a few centuries later, the ways in which Marguerite de Navarre uses confession in the Heptaméron reflect the changing status in the usage of the sacrament of penance between 1350 and 1550. No longer is the sacrament confined to the conversation between priest and penitent. Confession is seen to be equally effective when made to another member of the community; Marguerite's text explores alternative models of confessional interlocutors (diplomats, women, the author herself). The corruption of the Church and, more particularly, of 
the sacrament of confession is made amply evident in some of Marguerite's tales, and the increased focus on the narrative of the individual, rather than collectively experienced sins, comes to light in these stories.

If establishing any kind of epistemological history of confession after Lateran IV seems out of reach from today's perspective, readers are nonetheless left with a rich literary archive from which to cull. Because of the explicit link between the Decameron and the Heptaméron, mapping sacramental confession in both texts can shed new light on the social repercussions of Lateran IV from the time of its enforcement to the religious turbulence of the Reformation and Counter-Reformation. ${ }^{7}$ At the same time, I hope that my reading will inspire other explorations of the previously under-studied link between penance as a contentious social rite and its textual manifestations in medieval and early modern literature.

\section{Following the Formula: False Confession in Decameron 1.1}

The opening novella of the Decameron features a false confession performed by a wicked man on his deathbed. ${ }^{8}$ Readers learn that the protagonist, Ser Ciappelletto, "testimonianze false con sommo diletto diceva [would take great delight in giving false testimony]" (1.1.11). Furthermore, he was a "bestemmiatore di Dio e de' Santi era grandissimo, e per ogni piccola cosa, sí come colui che piú che alcuno altro era iracundo. A chiesa non usava giammai, e i sacramenti di quella tutti come vil cosa con abominevoli parole scherniva [a mighty blasphemer of God and His saints, losing his temper on the tiniest pretext, as if he were the most hot-blooded man alive. He never went to church, and he would use foul language to pour scorn on all of her sacraments, declaring them repugnant]" (1.1.13-14). The narrator makes Ser Ciappelletto's stance on the sacraments very clear, and the final verdict on his character culminates in the exclamation that "egli era il piggiore uomo forse che mai nascesse [he was, perhaps, the worst man ever born]" (1.1.15). As a result, he is often hired to do the dirty work of other men. When he is sent to France on an assignment to collect money on the Franzesi's outstanding loans, he suddenly falls gravely ill and is left in the care of two brothers who are at a loss as to how to handle the precarious situation.

The two men immediately begin to quarrel about whether or not to send for a priest to take Ser Ciappelletto's last confession. On the one hand, they know that by turning him out of the house, they will lose 
credibility in the eyes of their fellow townspeople. However, they are equally troubled by the prospect of sending for a priest because of the gravity of his sins; convinced that he will refuse to confess, they are concerned that Ser Ciappelletto will be denied absolution and sent to a dishonourable death at their expense (1.1.22-6). Ser Ciappelletto overhears the two men quarrelling and assures them that they should not worry about the status of his mortal soul:

Io non voglio che voi d'alcuna cosa di me dubitiate né abbiate paura di ricevere per me alcun danno. Io ho inteso ciò che di me ragionato avete e son certissimo che cosí n'averrebbe come voi dite, dove cosí andasse la bisogna come avvisate: ma ella andrà altramenti. Io ho, vivendo, tante ingiurie fatte a Domenedio, che, per farnegli io una ora in su la mia morte, né piú né meno ne farà; e per ciò procacciate di farmi venire un santo $\mathrm{e}$ valente frate, il piú che aver potete, se alcun ce n'è; e lasciate fare a me.

[I don't want you to worry in the slightest on my account, nor to fear that I will cause you to suffer any harm. I heard what you were saying about me and I agree entirely that what you predict will actually come to pass, if matters take the course you anticipate; but they will do nothing of the kind. I have done our good Lord so many injuries whilst I lived, that to do Him another now that I am dying will be neither here nor there. So go and bring me the holiest and ablest friar you can find, if there is such a one, and leave everything to me.] (1.1.27-9)

The men decide to send for a holy man who is held in great esteem by the people of the community (1.1.30). When the friar appears to take the sick man's confession, Ser Ciappelletto, showing some knowledge of confessional procedure, responds in line with the deathbed protocol of making a general confession of one's sins before receiving extreme unction at the time of death:

$\mathrm{Al}$ quale ser Ciappelletto, che mai confessato non s'era, rispose: "Padre mio, la mia usanza suole essere di confessarsi ogni settimana almeno una volta, senza che assai sono di quelle che io mi confesso piú; è il vero che poi che io infermai, che son passati da otto dí, io non mi confessai tanta è stata la noia che la infermità m'ha data." Disse allora il frate, "Figliuol mio, bene hai fatto, e cosí si vuol fare per innanzi; e veggio che, poi sí spesso ti confessi, poca fatica avrò d'udire o di dimandare." Disse ser Ciappelletto: "Messo lo frate, non dite cosí: io non mi confessai mai tante volte né 
sí spesso, che io sempre non mi volessi confessare generalmente di tutti i miei peccati che io mi ricordassi dal dí che io nacqui infini a quello che confessato mi sono; e per ciò vi priego, padre mio buono, che cosí puntalmente d'ogni cosa mi domandiate come se mai confessato non mi fossi."

[Ser Ciappelletto, who had never been to confession in his life, replied, "Father, it has always been my custom to go to confession at least once every week, except that there are many weeks in which I go more often. But to tell the truth, since I fell ill, nearly a week ago, my illness has caused me so much discomfort that I haven't been to confession at all." "My son," said the friar, "you have done very well, and you should persevere in this habit of yours. Since you go so often to confession, I can see that there will be very little for me to hear or to ask." "Master friar," said Ser Ciappelleto, "do not speak thus, for however frequently or regularly I confess, it is always my wish that I should make a general confession of all the sins I can remember committing from the day I was born till the day of my confession. I therefore beg you, good father, to question me about everything, just as closely as if I had never been confessed."] (1.1.32-4)

Given that Lateran IV mandated once-yearly confession, and that more frequent usage of the sacrament was not encouraged until several centuries later (in the decades preceding the Council of Trent), the fourteenthcentury reader would immediately have been struck by the ridiculous tone of Ser Ciappelletto's imaginary weekly confessions. Despite the priest's rather astonishing willingness to take the false penitent at his word, however, Ser Ciappelletto insists on performing the sacrament true to the form of a last confession, which would indeed have demanded a full narrative of the sins from birth to deathbed. Readers who know the extent of Ser Ciappelletto's wickedness now realize the rules of the game.

When the dying man bids the friar to "question me about everything, just as closely as if I had never been confessed," readers might smile at the irony of the situation, because they know that this will, indeed, be Ser Ciappelletto's first sacramental confession. It is not, however, his first textual confession. In other words, while Ser Ciappelletto has no intention of making his sins known to the priest, and intends to continue them to his death, the text has confessed them on his behalf. The reader is made well aware of Ser Ciappelletto's true nature before he falls ill; if ever one is in doubt about his true character, the narrator ruthlessly underscores that he was the worst man ever to have lived. 
Together with the recounting of his many sins (discussed above), there is another layer of confession in play. If the text cannot verbally speak, the storyteller can; thus, although textually bound in his turn, Pamphilo (the narrator of story 1.1), by speaking to an audience, confesses Ser Ciappelletto's sins on his behalf. The text both encompasses the dying man's true identity and also points to the inherently verbal nature of sacramental confession.

Aware of the irony already in play before Ser Ciappelletto begins recounting his "sins," readers are likely amused by the false confession that follows. But they might not be aware that in his examination, the friar follows the formula of confession manuals, which began to appear in increasing numbers following 1215 . He goes through a list of mortal and venial sins, following up his inquiries with gentle, probing questions. ${ }^{9}$ He begins with carnal knowledge of women (1.1.36), then proceeds to ask about gluttony (1.1.41), avarice (1.1.44), anger (1.1.47), bearing false witness, cheating, and stealing (1.1.53-4). ${ }^{10}$

The friar is dumbfounded by Ser Ciappelletto's over-zealous confession; Ser Ciappelletto "admits to" and condemns sins so trivial and doctrinally insignificant that even the friar admits to having committed them (1.1.57-8). Ser Ciappelletto shows an understanding of which sins would have been condemnable and why, suggesting widespread familiarity not only with the proceedings of the sacrament but also with the explanations that appeared in the confessional manuals for priests. Because the Decameron is not a devotional text, the overlap in vocabulary between confession manuals and Ser Ciappelletto's recall of confessional protocol makes it seem likely that priests quoted from manuals word for word or paraphrased the explanations. It also suggests that those performing the sacrament quickly learned the procedure and vocabulary of how to confess. At the same time, confession bears an element of communal education, as presumably everyone confessing to a similar sin would receive the same explanation of why it was wrong. ${ }^{11}$

There are other indicators of the communal orientation of the sacrament. Indeed, despite the community of readers who know better, the fictional community embedded in 1.1 appears to benefit from Ser Ciappelletto's false confession. The friar leaves, convinced that Ciappelletto is the most pious and virtuous man he has ever encountered. He willingly grants the dying man's request to send for the consecrated Body of Christ and performs extreme unction (1.1.76). After his death, Ciappelletto is praised by the friar during a Sunday sermon, the other clergymen in the community pray over his body for days, and a statue 
is erected in the marketplace to honour his virtuous conduct. As John Bossy writes, "the original bearing of the sacrament was not individual but collective ... the effect of the sacrament is to restore a condition of peace between the sinner and the church."12 Though Ser Ciappelletto is a stranger to the community in which he dies, his penance, however ironic, fulfils the function of reconciling and strengthening the ties between the members of that community and the Church. By contrast, there is no textual evidence to support the theory that confession reconciles the dying Ser Ciappelletto with God, nor was this ever presented as the goal of his confession.

On the other hand, the presence and importance of the community cannot be denied. The fact that the two brothers overhear the false confession makes it much more "real" contextually:

Li due fratelli, li quali dubitavan forte non ser Ciappelletto gl'ingannasse, s'eran posti appresso a un tavolato, il quale la camera dove ser Ciappelletto giaceva dividea da un'altra, e ascoltando leggiermente udivano e intendevano ciò che ser Ciappelletto al frate diceva; e aveano alcuna volta sí gran voglia di ridere, udendo le cose le quali egli confessava d'aver fatte, che quasi scoppiavano.

[The two brothers, who strongly suspected that Ser Ciappelletto was going to deceive them, had posted themselves behind a wooden partition which separated the room where Ser Ciappelletto was lying from another, and as they stood there listening they could easily follow what Ser Ciappelletto was saying to the friar. When they heard the things he confessed to having done, they were so amused that every so often they nearly exploded with mirth]. (1.1.78)

Their presence here serves more than a comic function. If this confession is not a face-to-face encounter "between two people who would probably have known each other pretty well," as Bossy explains would have been the case in most medieval confessions, it is instead explicitly public, or, as was typically the custom, "in the not-so-remote presence of a large number of neighbours." ${ }^{13}$ Gesturing towards confessional privacy, the text upholds a structural separation; the partition separating the sick man from his eavesdroppers loosely resembles attempts at privacy in medieval confession. Though the traditional mandate of confessing in one's own church would have destroyed Ser Ciappelletto's trick, as his own priest would have known his true nature, removing 
him from his native environment endows the narrative with all the necessary elements of public sacramental confession. ${ }^{14}$

If Ser Ciappelletto's false confession at first reads as nothing more than a very clever trick, the dying man's confession cleverly re-manoeuvres the stakes of penance and absolution. First, the two men who summon the priest are the only people who know the true nature of the deceased scoundrel. The reader might recall that this knowledge is what made them pause before summoning the religious man to begin with:

Egli è stato sí malvagio uomo, che egli non si vorrà confessare né prendere alcuno sagramento della Chiesa; e, morendo senza confessione, niuna chiesa vorrà il suo corpo ricevere, anzi sarà gittato a' fossi a guisa d'un cane. E, se egli si pur confessa, i peccati suoi son tanti e sí orribili, che il simigliante n'avverrà, per ciò che frate né prete ci sarà che 'l voglia né possa assolvere.

[He has led such a wicked life that he will never be willing to make his confession or receive the sacraments of the Church; and if he dies unconfessed, no church will want to accept his body and he'll be flung into the moat like a dog. But even if he makes his confession, his sins are so many and so appalling that the same thing will happen, because there will be neither friar nor priest who is either willing or able to give him absolution]. (1.1.24-5)

Before the "confession" even begins, the two men know the truth. The reader, too, has learned about Ser Ciappelletto's depravity prior to his illness. Thus, the text has already done the confessing on behalf of its sinning subject. But this kind of confession cannot result in absolution, especially because, in the Catholic community, only an ordained priest could grant absolution; moreover, the confession heard by the friar in this text is a false one. Textual confession leads only to empty absolution, while the penitent's deception results in an absolution by the appropriate party which the reader understands as invalid. The two men listening, too, would have been aware of the prime importance of absolution (as indeed they explain in the passage above); it stands front and centre as the goal of the sacrament of penance.

In Decameron 1.1, the friar, his subject, and his narrator all show perfunctory familiarity with the protocols of a properly conducted confession as stipulated by the rules of Lateran IV. However, the friar's interpretive skills do not extend beyond the questions he is bound by 
protocol to ask. Ser Ciappelletto, on the other hand, slyly outmanoeuvres his confessor, demonstrating his ability to perform the sacrament to perfection. Ser Ciappelletto, known by readers to be a master of verbal manipulation, easily manoeuvres his way through the protocol of confession, anticipating and outwitting the friar at every turn. Ser Ciappelletto fakes his testimony with deceitful words and supplements his performance with the signs of his body: the friar "infers especially intense contrition from the tears and sighing that accompany the confession: he takes them as visible proof of the truth of the speech and believes he can actually see the contrition."15 Thus, if the friar's questions are based on a codified protocol, Ser Ciappelletto responds with codified performances of his own. He knows that his tears and sighs will be read in a certain manner that corresponds to the false front he is attempting to present as truth. Confession in this tale is ironic, predictable (and therefore performable), and void of all meaning, despite the fact that it fulfils the perfunctory purpose of extracting a deathbed confession. The tone of the novella points to an ironic, playful void in the relationship between the sacrament and the person receiving it. Confession, though mandatory, emerges as a rhetorical game between two equal sides, with Ser Ciappelletto gaining the upper hand after his death, despite the ruse of his performance. The outcome of the story underscores the reconciliatory function of public confession and penance that most scholars agree defined the sacrament for the first few centuries following Lateran IV. In this particular novella, however, only the reader and other non-religious observers can see the truth.

This textual irony could actually be a reflection of the interpretive limitations and rudimentary enforcement of the new rules surrounding sacramental confession. Ser Ciappelletto's confessions are indeed communally oriented, and the fact that the "real" confession is carried out textually bears the possibility of some kind of textual absolution. Within the narrative, the author shows some familiarity with the religious protocol of the sacrament as it might have occurred in his time. But at the same time, confession in this text bears witness to its own parameters. In the very first tale of his text, Boccaccio demonstrates the dangerous power of falsification, while rhetorically employing it himself. He shows an understanding of the penitential formula but twists it, choosing instead to illuminate its boundaries. Real confession can only take place at one remove from the fictional plot. And real absolution in this story, if indeed it can be granted to the worst man ever to have lived, must be rhetorical also; the only absolution Ser Ciappelletto can 
receive is the wink of the reader who appreciates the extent to which he is manipulating the penitential formula. Boccaccio endows his own text with the same authority he exhumes from the sacrament of confession.

\section{Raising the Stakes: Confession in the Heptaméron}

Michel Foucault famously delineated the links between sacramental confession, sexuality, power, and knowledge in the sixteenth and seventeenth centuries. He argues that the heightened insistence upon confession posited by the Counter-Reformation produced an increased interest in the flesh and sexuality, as well as a new emphasis on parsing the innermost desires of the individual, which in turn helped to create a culture of individual desires. He writes,

For a long time, the individual was vouched for by the reference of others ... [and] then he was authenticated by the discourse of truth he was able or obliged to pronounce concerning himself. The truthful confession was inscribed at the heart of the procedures of individualization by power ... one confesses in public and in private, to one's parents, one's educators, one's doctor, to those one loves; one admits to oneself, in pleasure and in pain, things it would be impossible to tell to anyone else. ${ }^{16}$

Foucault's contention - that confession became the modus operandi by which those in power were able to perpetuate their discourse of knowledge, and that individuals became so accustomed to this mode that they internalized it - is a powerful one, with significant implications. He identifies confession as an important component in parsing the network of early modern power, and he uses it to pinpoint a cultural shift during which the individual was simultaneously being confessed and learning the power of internal confession to one's self. While I believe that Foucault's argument is limited to one historical moment and one discourse at a time and, as such, does not account for the uneasy negotiation that often happens outside the text, or even within other contexts, it does provide a useful lens through which to read the evolution of confession since Lateran IV. In what follows, I will use several examples from the frame and stories of the Heptaméron to show the extent to which literary documentation of verbal confession has changed in the centuries separating Boccaccio and Marguerite de Navarre. By the sixteenth century, the focus in confession and penance has turned inward, in contrast to the public setting in Boccaccio's text. ${ }^{17}$ Marguerite's text reflects new 
values in the practice of confession, as well as the ways in which the trope of confession was interpreted by clergy and laypeople.

The method by which Marguerite de Navarre sets up her project in the Prologue already bears witness to the different environment in which the tales will be told. If the storytellers of the Decameron flee the city in order to escape the Plague, thereby implying physical and moral corruption, Marguerite's devisants find themselves stranded as the result of a massive flood. By alluding to the new covenant established after the great flood in Genesis, the Heptaméron thus sets a tone of reconciliation. The underlying message is one of resolution and equality; "au jeu," proclaims Hircan, "nous sommes tous égaux [Where games are concerned everybody is equal]" $(49 ; 70) .{ }^{18}$ The emphasis on parity need not be taken for granted; following every story, the devisants respond heatedly to the issue at hand, creating a narrative complexity that far exceeds the comparatively straightforward approvals given up by Boccaccio's brigata. At a time when religious uncertainty and difference would have been on everyone's mind, explicitly setting the record straight for the fictional frame characters allows them to speak freely and without fear. For the reader, it also sends the message that complexity and ambiguity will be the name of the game; if the devisants can freely debate their opinions, there will be no clear message as to which actions constitute sins, and no clear agreement about how to judge the characters in each novella. Other clues in the Prologue remind the reader of the sacramental setting in which the stories will be told. The devisants are stranded at the abbey of Our Lady at Sarrance; this backdrop sets a confessional tone. And lest the reader, or the frame characters, forget the seriousness of their predicament or their great debt to God for having saved them, they begin their day in prayer and then retreat to the abbey for inward reflection and more prayer at the close of each day of storytelling. Finally, Parlamente, one of the two strongest female voices in the frame, insists that the stories they will tell be true. ${ }^{19}$ The Prologue thus explicitly and deliberately establishes a contrast to the Prologue of Boccaccio's Decameron, which makes no such stipulation, and it more explicitly suggests a link between storytelling and confession. ${ }^{20}$ The link is strengthened if one considers that on more than one occasion, the resident monks are caught listening to the tales from the bushes. Not only are "real" confessors present, they openly enjoy the stories they hear, suggesting that listening to secrets is pleasurable and takes the listener beyond the call of duty. If listening is pleasurable even for professional confessors, the communal pleasure of the devisants and their 
eavesdropping companions implies that the act of listening to confession is open to anyone. This is an explicitly Reformed idea; Calvinism and other branches of Protestants insist that confession is a communal rite that can be performed to and by any member of the religious community. The frame, then, ensures that the "official" backdrop is textually and metatextually present, and that confession will play a major role in the framework of the stories. Instead of merely pointing to an awareness of confessional protocol, the Heptaméron sets up, even beyond the narrative scope, a textual setting that demonstrates acute awareness of confessional elements.

All of this is certainly not to say that the French text does not have its fair share of falsified confession and deceit. In Novella 60, an unfaithful wife takes up with one of her husband's cantors while he is away. In order to escape suspicion, she feigns grave illness, and sends for "quelques femmes de bien de la ville pour la venir visiter [some of the honest women of the town to come and visit her]" (429; 471). Having surrounded herself with a community of listeners, she "fit semblant de pleurer et de connaître son péché, en sorte qu'elle faisait pitié à toute la compagnie qui cuidait fermement qu'elle parlât du fond de son coeur [pretended to weep and admit her sins, with the result that all these good ladies, who thought she was speaking from the depths of her heart, were moved to pity]" $(429 ; 471)$. Having been duped into believing the woman repentant, they immediately send for a religious man to hear her confession (ibid.). He takes her confession, apparently without issue, seeing as there is no mention of it in the body of the text, and he administers extreme unction to the purportedly dying woman. She fakes her death, and after her funeral the cantor digs her up; they go on to live together happily for some years until the truth comes out and she is forced to reconcile with her husband. Two important differences separate this text from Novella 1.1 in the Decameron. First, while in the Italian text Ser Ciappelletto gets away with his falsified confession, even drawing together the community in the aftermath of his death, this woman is eventually found out. As confession is no longer a formulaic gesture, its representations in sixteenth-century texts insist on digging deeper until things are made right. Oisille, the spiritual leader of the frame narrative, exclaims at the end of the discussion, "Je crois que ce n'est pas pour chercher la confession qu'elles [depraved women like the one in Novella 60] cherchent les confesseurs ... elles regardent de s'arrêter au lieu qui leur semble le plus couvert et le plus sûr, que de se soucier d'avoir absolution du mal dont elles ne se repentent point 
[I do not think that [they] pursue confessors in order to make their confession. They are ... really looking for ... the opportunity to sin in secrecy and security rather than the opportunity to seek absolution for sins of which they do not in the least repent]" (431-2; 474). Oisille's stance on the matter acknowledges critical awareness of the abuse of the sacrament in ways Boccaccio's text does not. And despite Marguerite's decidedly female voice in the text, she does not shy away from admonishing those of her own sex who would manipulate a religious sacrament that appears, in her view, to be valuable.

At the same time, the context in which this honest confession should take place appears to be a matter of debate (as indeed was the case in sixteenth-century Reformation Europe). While Marguerite's version does follow the requisite procedures of the sacrament of penance (administering extreme unction after a deathbed confession to a priest), the actual confession to the priest is textually omitted. The woman does tell her fake story to a community of honest women - but this is all the readers know. Though one can assume she repeats the same confession to the priest, the role of the religious man in the sacrament of confession is minimal. Whereas in Decameron 1.1 the dupery continues over several paragraphs, and is all the more significant because of its adherence to confessional manuals, here readers learn more about the corruption of the Church and its members than they do about the confession itself. And, after all, the woman in question is sleeping with her husband's cantor. In the end, Boccaccio's text reveals a familiarity with the sacrament of penance (despite its formulaic emptiness). Marguerite's, on the other hand, has moved beyond simple acknowledgment of the sacrament; while both authors highlight the corruption of the Church, the stories in which confession appears in the Heptaméron highlight the changing nature of the sacrament since Lateran IV and since the time when Boccaccio penned his own collection of tales.

Novella 41 features a singular Christmas Eve confession. ${ }^{21}$ Having sent for "un prêcheur suffisant et homme de bien, tant pour prêcher que pour confesser elle et toute sa maison [a competent, honest man who could preach, as well as hear confessions from herself and her whole household]" $(340 ; 377)$, the Countess of Aiguemeont sends her entire household to confess. The text invokes the tradition of annual confession before receiving the sacrament of communion, usually on major holidays such as Christmas or Easter. The Countess takes the first turn, at which point the text explicitly points out the private setting of her confession: "après s'être confessée en une chapelle bien fermée, 
afin que la confession fût plus secrète [she made [her confession] in a chapel behind closed doors for the sake of privacy]" (ibid.). Private confessional booths were not commonly used in France until later in the century, but the novella marks a shift away from public confessions that take place within earshot of the rest of the community. As a result, the dynamic of what is spoken in confession is explicitly private, with both the sins of the penitent and the reaction of the confessor beyond the reach of public knowledge.

After the Countess makes her confession, she sends her lady of honour, who in turn sends her daughter, to do the same. As readers, we are privy to the conversation that takes place between the girl and her confessor in the novella. However, it is worth pointing out that, although we learn that the girl shares seemingly salacious details of a sexual nature about her private life, we do not actually have access to the exact content of her confession. If Ser Ciappelletto shows an acute awareness of the formula of confession in his deathbed trick, the dynamics of confession in this novella extend far beyond simple manipulation. Instead of extracting sins with legal or communal consequences, the priest here focuses on private details of a very personal nature. He does not appear to have followed the same handbook as Boccaccio's friar; indeed, there is no indication of a formula at all. Though the details remain securely out of the reader's grasp, the text points to the priest's response as one of sexual excitement.

The text thus maintains control over the secret of the confession..$^{22}$ Readers must come to their own conclusions based on the reaction of the preacher, which the text itself proclaims to be "non accoutumée [strange]" $(341 ; 378)$. He orders the girl to wear his cord against her bare flesh as a penance for her sins. And he insists that he fasten the cord around her with his own hands $(341 ; 377-8)$. The girl, who is seemingly versed enough in the procedure of the sacrament to be sceptical of the appropriateness of this particular penance, refuses. The preacher accuses her of being a heretic, and refuses absolution. His refusal, as Mary B. McKinley writes, "reflects the early-Reformation polemic on sacramental confession and indicates Marguerite de Navarre's position in that debate." ${ }^{23}$ Marguerite intentionally illuminates the manipulative power invested in the sacrament and textually sympathizes with the perspective of Reformers. The innocent, duped girl emerges from the confession "la conscience bien troublée, car elle ... avait peur d'avoir failli au refus qu'elle avait fait au père [with a troubled conscience ... and afraid lest she had done wrong in refusing the priest]" $(341 ; 378)$. 
The novella is resolved when she recounts the details of the failed confession to her mother, who in turn tells the Countess, who has the priest whipped until he admits the truth $(342 ; 378)$. These two "confessions" that follow the official sacrament comment on the corruption of the office of the Church and imply that, when it comes to extracting a confession in order to achieve justice, laypeople have taken the sacrament into their own hands. The sacrament of the confession, though increasingly personalized and private, holds no legal weight, nor is penance necessarily just, nor does penance, when applied, necessarily result in absolution. The characters in the novella reveal a lay population at the mercy of an essentially empty sacrament, on the one hand, and with the power to implement alternative techniques of truth, justice, and absolution, on the other. By displacing resolution from the priest to the Countess, Marguerite offers an alternative to the problem of one-sided confession in which the priest has unequivocal power.

Both elements reappear in Heptaméron 72. Here, a young nun is left in the company of a monk at the bed of a dying man. After administering extreme unction and receiving the confession of the man, they both comfort him in his transition to death. Immediately thereafter, the monk rapes the nun. In order to prevent a public scandal, the monk warns the naive girl to "[ne pas] se confesser à autre qu'à lui [not to mention it in her confessions to anyone except himself]" $(495 ; 541)$. The girl continues to come to the monk for absolution, which leads to an eventual pregnancy. Unable to reveal the corrupt monk's nature, she leaves the convent, hoping that "en confessant son péché aux pieds du pape, recouvrer sa virginité [if she made her confession at the feet of the Pope, she could recover her virginity]" $(496 ; 541)$. When she gets as far as Lyon, the nun is interrupted at prayer by Marguerite herself, and once the girl learns to whom she is speaking, she confides in her, "[se jetant] à ses pieds ... pleur[ant] et cri[ant] [(throwing) herself at her feet, weeping once more and crying out loud]" $(497 ; 542)$. After encouraging the girl not to relinquish her repentant spirit, the duchess intervenes on her behalf, "avec lettres à l'évêque du lieu pour donner ordre de faire chasser ce religieux scandaleux [with letters to the bishop of the diocese, instructing him to have the scandalous monk removed]" $(497 ; 543)$. The author enters the text and takes the role of confessor, granting absolution to the nun in the seventy-second story and removing the clearly corrupted false monk from his position. ${ }^{24}$ Not only does confession take place outside the official realm of the sacrament - Marguerite explicitly discourages the nun from seeking confession from the pope, the most 
high and holy of confessors - but Marguerite's political and personal position of wealth and power allow her to identify and remove the broken link in the confessional chain.

Readers can find more evidence of lay confessions in other tales, and I would point especially to Heptaméron 32, in which a German diplomat hears confessions from a man who subjects his unfaithful wife to a macabre and unusual punishment, then convinces the husband to absolve his wife of her sins. ${ }^{25}$ The confession trickles down from the husband, who tells the story on his wife's behalf, to the visiting diplomat, who then speaks directly to the guilty wife. She treats their encounter as a confession: "Monsieur, je confesse ma faute être si grande que tous les maux que le seigneur de céans ... me saurait faire ne me sont rien au prix du regret que j'ai de l'avoir offensé [Monsieur, I confess that my sins are so great that all the suffering that is inflicted upon me by the lord of this house ... is as nothing compared with the remorse I feel in having wronged him]" (297; 333). After leaving their household, the diplomat tells her story at court, from whence it makes its way to the fictional storyteller of the frame narrative. The wife's adulterous secret certainly is not held to the same promise of confessional anonymity that at least theoretically existed in the sacrament, but it is just as effective; the diplomat, upon hearing the story, grants the evidently penitent wife absolution and advises the husband to forgive her, if only for the possibility of continuing the family line. His language bears traces of the absolution given after sacramental confession: "vu la grande repentance de votre pauvre femme ... vous devrez user de miséricorde [As your wife's repentance is so deep, it is my belief that you should show some compassion towards her]" (298; 333). Just as Marguerite's presence in Novella 72 plays a diplomatic function of standing between the girl's sin and the Catholic Church, here the diplomat negotiates the confessions of husband and wife and offers a path to absolution that occurs explicitly outside the realm of the Church.

Confession, in the context of the Heptaméron, only works when it is removed from the sacramental framework in which it was intended to be performed according to the mandates of Lateran IV. While the frame of the text takes care to establish an explicitly confessional setting, the confessions that take place within the tales are much less conventional. If the frame playfully and dialogically vacillates between sacramental and worldly spaces, subverting the spiritual aspects only to re-establish them at the end of each day, the stories themselves bear 
out a different history. To be sure, the implicit and explicit references to confession throughout the Heptaméron bear witness to a continued prevalence of the trope of confession between the fourteenth and sixteenth centuries. Writings such as the Decameron and the Heptaméron reflect both the prominence and knowledge of the sacrament among layfolk. And both texts point to the challenges of defining the role of confession in the centuries following Lateran IV, particularly as the poles of public and private, and the regulations of each, were under constant negotiation.

Boccaccio's text demonstrates a remarkable familiarity with the conventions of the sacrament of confession. Story 1.1 points to a correlation between the largely communal, legal emphasis of confession in the first few centuries following 1215, and playfully subverts the authority of those performing confession. The Heptaméron, on the other hand, reflects the religiously charged time during which it was written, particularly concerning the corruption of the clergy and the need to confess to a designated spiritual leader, as opposed to any other member of the community. Marguerite de Navarre, who was a religious and political leader in her own right, recognized the hermeneutic tension contained within the hotly contested sacrament of confession, and transformed her text into a confessional space where the most pressing religious and social concerns of her time come to light.

Both the Decameron and Marguerite de Navarre's Heptaméron share a deep interest in documenting and debating the impact of religion in their respective times. Both metaphorically shed light on the corruption of society (the brigata is fleeing the Plague; the deviants, a catastrophic flood) and in particular, the Church. Religion is written into the frame of both texts, and often cannot be separated from the fabric of storytelling. For example, the brigata meet in a church, Santa Maria Novella (a name that binds together storytelling and religion). Daily prayer shapes every day of the frame narrative, as it does in the Heptaméron. In the later text, the devisants are stranded at an abbey, and the monks who host them are implicitly involved, though not explicitly included, in the storytelling. Both texts often insist that the people whose tales they tell are real, a technique that blurs the line between truth and fiction, and one that makes the text itself a site of confession. Because some details are only known to readers, and because the text fulfils or even stands in for the sacrament of confession, these texts, in the very fact of their textuality, participate in reforming confession, even as they both reflect its corruption in practice. 


\section{NOTES}

1 http://www.ewtn.com/library/councils/lateran4.htm\#14.

2 The secondary literature on the history of sacramental confession is vast. For an informative overview of the evolution of the sacrament, see the article "Penitence," by E. Amman and A. Michel, in the Dictionnaire de théologie catholique, 1st ed. (Paris: 1909-50), esp. chaps. 4-8. See also Jaroslav Pelikan's The Christian Tradition: A History of the Development of the Doctrine, vol. 3, Reformation of Church and Dogma (1300-1700) (Chicago: University of Chicago Press, 1984). For a sympathetic but still critical account, see John T. McNeill, A History of the Cure of Souls (New York: Harper, 1951). A good collection of primary sources and essays with a primarily socio-historical focus is A New History of Penance, ed. Abigail Firey (Leiden: Brill, 2008). For an account of how the sacrament was practised in the Middle Ages, see Handling Sin: Confession in the Middle Ages, ed. Peter Biller and A.J. Minnis, York Studies in Medieval Theology II (York: York Medieval Press, 1998). Finally, Thomas N. Tentler's study on the evolution and significance of the sacrament is an invaluable resource; see Sin and Confession on the Eve of the Reformation (Princeton: Princeton University Press, 1977).

3 See, for example, Merry E. Wiesner-Hanks, Christianity and Sexuality in the Early Modern World: Regulating Desire, Reforming Practice (London: Routledge, 2000), 110. David Myers also takes this stance. See "Poor, Sinning Folk": Confession and Conscience in Counter Reformation Germany (Ithaca: Cornell University Press, 1996), 33; 45; 56; and 192.

4 My search for the term "confess" rather than "confession" was deliberate; it was meant to include hits of the verb "to confess" as well as the noun.

5 Alexander Murray, "Confession before 1215," Transactions of the Royal Historical Society, 6th ser., 3 (1993): 51-81; and John Bossy, "The Social History of Confession in the Age of Reformation," Transactions of the Royal Historical Society 25 (1975): 21-38.

6 Though it focuses on a different theme and set of texts, Franklin Lewis's chapter in this volume argues, as I do, that part of Boccaccio's project is to situate a theme (deception) within a larger narrative.

7 Marguerite de Navarre, Heptaméron, 1559, ed. Simone de Reyff (Paris: Flammarion, 1982); English translation by P.A. Chilton (New York: Penguin, 1984). Marguerite was familiar with Boccaccio's text, having commissioned a new translation into French. And in the Prologue to the Heptaméron, the devisants invoke the Decameron as a model for their own storytelling project (47-9). 
8 Quotations from the Decameron are from Giovanni Boccaccio, Il Decamerone, 1353, ed. Vittore Branca (Decameron Web, 30 August 2013); English translations by G.H. McWilliam, 2nd ed. (New York: Penguin, 1995). The opening novella is not the only one in which confession plays a major role (other notable examples include 3.3 and 7.5). Limits of space prevent a more thorough analysis of all three of these stories. I have chosen to focus on this one example because it so explicitly follows certain formulaic conventions and because it very poignantly highlights the prevalence of sacramental confession in a fictional setting.

9 For some examples of confession manuals from Boccaccio's time, see Joseph Goering, "The Internal Forum and the Literature of Penance and Confession," Traditio 59 (2004): 175-227; 223-4.

Some later examples include Short Instructions for Validly Making Sacramental Confession (Jodocus [morder] Winshemius [Erfurt, 1515]), Confessionale (Nuremberg: Engelhardus Kunhofer, 1502), Penitentiarius (Nuremberg: Romming, 1522?), and an anonymous Manual for Parish Priests. Jean Delumeau examines confession manuals in L'Aveu et le Pardon: Les difficultés de la confession XIIIe-XVIIIe siècle (Paris: Fayard, 1990). See also Anne Jacobson Schutte, “Consiglio Spirituale e controlo sociale: Manuali per la Confessione stampati in volgare prima della Controriforma," in Città Italiane del'500 tra Riforma e Controriforma: Atti del Convegno Internazionale di Studi, Lucca, 13-15 ottobre, 1983 (Lucca: Maria Pacini Fazzi Editore, 1988), 45-59.

10 This particular passage resonates with the index of Tommaso de Vio Cajetan's Summa caietani: summula de peccatis / reuerendissimi domini Thomae de Vio Caietani s. xisti, sacrae Theologiae professoris celeberrimi, recentissime Summarijs aucta dignissimis ; praeposito sente[n]tiarum specialium repertorio, nunc primum edito; accedit ite $[\mathrm{m}]$ de Noui Testamenti Ientaculis tractatus eiusdem excellentissimus (1539). Each heading points to the place in the text where one might learn how to question a penitent about a specific sin, for example, under "I," idolatry, impiety, ingratitude, or incest.

11 Though it is a later example of this kind of knowledge, Bertin Bertaut's catechism for confessors (Le directeur des confesseurs, en forme de catechisme: contenant une methode nouuelle, briéue \& facile pour entendre les confessions, 1662) divides penitents by their professions and status in life, then predicts common sins for each group and explains whether these sins are mortal or not.

12 Bossy, "The Social History of Confession in the Age of Reformation," 22.

13 Ibid., 24.

14 Confessionals with a grill or screen separating the penitent from confessor were not commonplace in the Church until the mid-sixteenth-century. 
Until then, confession commonly took place in the pews, or in a small chapel - off to the side but by no means private. See Wiesner-Hanks, Christianity and Sexuality in the Early Modern World, 116, and Myers, "Poor, Sinning Folk," 134-5.

15 Irene Albers, "The Passions of the Body in Boccaccio's Decameron," MLN 125, no. 1 (2010): 26-53; 42.

16 Michel Foucault, The History of Sexuality, Vol. 1: An Introduction, trans. Robert Hurley (New York: Vintage, 1978), 58-9. See also Wiesner-Hanks's account in Christianity and Sexuality in the Early Modern World.

17 Goering, "The Internal Forum," 226.

18 All English citations are from P.A. Chilton's translation (New York: Penguin, 1984). The second page number cited refers to the English edition.

19 One might make a connection between the frame's emphasis on truth and the narrator's insistence in the sixty-second novella that her story is true (which is directly followed by a confession of self). I am not implying that the devisants are all engaging in confessions; rather, that their emphasis on the veracity of the tales shows their investment in the tales. The emphasis on truth also provides the authoritative justification for telling tales in the first place, and it also qualifies any inappropriate pleasure they might experience.

20 Though Boccaccio's storytellers do insist on various occasions that their tales are true (see Dec. 9.5.5), it is not written into the framework of their project in the same way as in Marguerite de Navarre's text.

21 Mary B. McKinley, "Telling Secrets: Sacramental Confession and Narrative Authority in the Heptameron," in John Lyons and Mary B. McKinley, Critical Tales: New Studies of the Heptameron and Early Modern Culture (Philadelphia: University of Pennsylvania Press, 1993), 146-71. McKinley's chapter provides a rich analysis of sacramental confession in this novella, as well as in Tales 22 and 72. Her larger emphasis in the piece is on the female narrative authority placed strategically into confessional spaces, but I draw much of my reading of Novellas 41 and 72 from her discussion of the ways in which Marguerite de Navarre's views on absolution and penance coincide with those of many of the early Reformers ostracized in François I's Catholic court. She writes that "penance was a bone of contention in the early Reformation, not only because it implied the efficacy of good works, but because of the passionately contested practice of indulgences ... To assign as penance the repetition of the very sin that had brought the penitent to confession would have required a striking perversion of the confessor's role" (161). 
22 See ibid., 156.

23 Ibid., 146.

24 See ibid., 159-63. McKinley's reading has inspired mine, particularly in her conviction that "the confessor uses penance as a means of sexual coercion" (160) and in her analysis of how the way Marguerite intervenes in the text corresponds to the Reformers' critique of the corruption to which the sacrament of penance had succumbed (162-3).

25 Other stories in which the Heptaméron offers implicit or explicit insight into sacramental confession include Tales 22, 25, and 67. 
This page intentionally left blank 